\title{
Higher Education Policy: the evolution of a journal revisited ${ }^{i}$
}

\author{
Jeroen Huisman, editor HEP \\ Department of Sociology \\ Ghent University \\ 9000 Ghent, BELGIUM \\ Jeroen.huisman@ugent.be
}

\begin{abstract}
This paper reflects on the contributions to the journal Higher Education Policy, celebrating its $25^{\text {th }}$ birthday. It describes and analyses the themes addressed by the authors and the institutional background of the 1,172 contributors to the 812 papers. The analysis confirms the focus of the journal on higher education policy, governance and management and its truly international character with contributions from across the globe on issues at stake in a vast range of countries and institutions. Additionally, the paper analyses patterns regarding highly-cited contributions to the journal and closes with words of thanks and recommendations for those intending to submit a paper to the journal.
\end{abstract}

Keywords: higher education policy; journal; evolution; content analysis

\section{Introduction}

In volume 21 of this journal, I looked back at twenty years of Higher Education Policy and presented data on themes addressed, contributors and their affiliations and the geographical spread of the authors (Huisman, 2008). I thought it worthwhile to do this again in light of the celebration of the twenty-fifth anniversary of the journal. It is not only fun to describe and analyse trends and deviations from trends, it appears to be part of an emerging development of higher education researchers reflecting on the state of the art in this field (see e.g. Tight, 2012; Dobson, 2009; Bray and Major, 2011; Goodyear et al., 2009).

I will address the same topics as five years ago, but will in some of the analyses contrast the past five years with the preceding two decades to be better able to spot any significant changes. Additionally, I will pay some attention to citation patterns. In 2012, the journal was selected by Thomson Reuters for inclusion in the Social Sciences Citation Index (SSCl). With increasing access to fairly robust data on citations, it seemed worthwhile to analyse which papers in the Higher Education Policy history have been cited regularly and to reflect on this as well. Is there a recipe for becoming a highly-cited Higher Education Policy author? 


\section{Methodology}

A spread sheet was created that contained in subsequent columns: the title of the contribution, the author(s), the issue in which the paper appeared and the affiliation(s) of the author(s) (organisation and country). Some contributions were left out, such as anonymous contributions, book reviews, and single-authored editorials by the current and previous journal editor. Also contributions that did not go beyond mere description of a policy (or even were excerpts of such documents) or of an institutional-level development - were excluded. In all, about 110 contributions - the majority being editorials of the former editor of the journal - were left out of the analysis. The database contained 812 papers (656 in 2008), starting with George Psacharopoulos' (1988) The Financing of Education in Developing Countries and closing with Henning Kroll and colleagues' (2013) Scope and Determinants of the 'Third Role' of Higher Education Institutions in Germany.

Methodological problems were easily addressed, having learned from the previous analysis. Data were carefully checked for different spellings of names of authors and for changes in affiliations. A small percentage of authors moved to other higher education institutions during their "Higher Education Policy career", sometimes within a country, sometimes between countries. In the case an author gave two affiliations for a particular paper, the first affiliation was chosen, assuming this would be the main affiliation, unless I knew the particular author reasonably well and thought it more appropriate to select the second affiliation. In case of affiliations lacking, I used my own memory or a quick Internet search to find the affiliation. Not only authors move, but the social geography of the world changes as well. I decided to use contemporary names of countries (hence e.g. Russia, not USSR). I am confident that most ambiguities have been solved. There may have been the odd mistake in a couple of cells of the spread sheet, but this has not significantly influenced the overall presentation and analysis.

Regarding the analysis of themes, I looked at words in the titles of the contributions. For sure, this is not an optimal methodology in terms of reliability. Content analysis of papers would have been more appropriate, but rather time-consuming, even though I have read - in my role of editor - various versions of all contributions since 2007. Titles are supposed to summarise and reflect content and hence this was taken as a point of departure. Words that were considered meaningless (for the objective of the analysis), like "the", "a" and "of" as well as many verbs and adjectives were left out of the analysis. Also country and institutional names were left out. Variants of words - for example "education(al)", "educating" and "educated" - were taken together under one heading.

For the analysis of the citations, I made use of Anne-Will Harzing's "publish or perish" web site (June 2013), which uses Google Scholar for finding and counting citations of authors or of contributions to a particular journal. The software also produces citations per year, which makes comparisons of older versus newer papers somewhat easier.

\section{A change in objectives}

The 2008 analysis detailed the gradual change of focus of the journal from an exchange of information and experiences towards a more traditional scholarly approach. Eberhard and Thorens $(1988,6)$ claimed that the journal 'would focus on policy issues and the role of higher education in 
society today, and also will carry reports on relevant research being carried out in various parts of the world' (Eberhard and Thorens, 1988, 6). The current aims and scope are:

'Higher Education Policy is an international peer-reviewed journal, indexed in the Social Science Citation Index (SSCl), under the auspices of the International Association of Universities (IAU), for advancing scholarly understanding of the policy process (development, implementation, impact and responses) applied to higher education. It does so through the publication of original analyses: theoretical, empirical or practice-based. However, empirical or practice-based contributions need to be theoretically or conceptually embedded. Contributions may be either based on qualitative or quantitative methods (or a mixture). The focus of the analysis may range from case studies of developments in individual institutions to policy-making at system and supra-national levels. Higher Education Policy encourages contributions that make explicit comparison between systems of higher education and studies that build on developments in the related (social sciences) disciplines' (Higher Education Policy, 2013).

The international dimension is clearly visible, for there have been contributions from all continents, from A (Algeria) to Z (Zimbabwe), but still nothing from the Antarctic. The shift in focus materialised in different ways (Huisman, 2008, 267-268). First, papers in the early volumes were not or hardly referenced. Second, many of the - often single-authored - contributions were written by institutional leaders or representatives, or representatives from national agencies like ministries, buffer organisations and international agencies such as the IAU, OECD and World Bank. Third although not necessarily unambiguously distinguishing informative and scholarly contributions - the earlier contributions were much shorter. In the first 2 years (1988 and 1989) contributions were on average 9.5 pages long, having recalculated the length of the then $A 4$ format contributions into the present format. Those appearing in 2006 and 2007 were almost twice as long: 18.2 pages (Huisman, $2008,267-268)$. In the last five years, the average length of a paper even increased to 22.5 pages.

\section{Themes addressed}

The following table presents the most used words in titles of articles in Higher Education Policy (Table 1). The appearance of the words "bottles", "friends", "beach" and "bodies" in the very long list of words in the titles at first caught me by surprise, but it turned out these words were outliers. The full titles (e.g. Study or beach? Students' motivations and attitudes regarding summer session, Intermediary bodies and universities: autonomy in Turkey and Old wine in new bottles? A comparison of public and private accreditation schemes in higher education) explained the situation.

Words like "education", "higher" and "policy", true to the title and focus of the journal appeared most often. Also, the occurrence of words like "university" and "academic" do not strike us as odd. A fair number of often-used words denote something technical or methodological aspect of the studies carried out, like "case", "study", "perspective" and "research". The latter term obviously has various meanings, not only hinting at research as in "investigation", but also as an object of investigation. The high frequency of words like "change", "new", "challenge", "development" and "reform" are not a surprise, in light of the important changes taking place in the field of higher education, but obviously also because researchers and observers are not so much triggered by and enthused to 
write about things that do not change. Comparing table 1 with the list of five years ago reveals a pattern of continuation, rather than change. The only new word is "comparative", but this term was already used a lot in the first two decades. Words that dropped out of the top-25 were "culture" and "state". Words - leaving aside technical terms - that appeared quite often since 2008, but did not make it (yet) into the overall top-25 were e.g. "globalisation" (10 times), "diversity" (8 times), "knowledge" (8 times), "mission" (5 times) and "leadership" (5 times), hinting at both the changing higher education context (knowledge [economy], globalisation) and the increasing importance of the higher education institution as an actor (mission, leadership, strategy) (see also Krücken and Meier, 2006).

Table 1 Top-25 of words appearing in the titles of contributions $1988-2013$

\begin{tabular}{|l|r|}
\hline Word & Frequency \\
\hline & \\
\hline Educated/education(al)/educating & 389 \\
\hline Higher & 293 \\
\hline Universities/university & 270 \\
\hline Policies/policy & 96 \\
\hline Developed/developing/development(al) & 75 \\
\hline Academic(s) & 74 \\
\hline Research & 68 \\
\hline Case(s) & 66 \\
\hline Institution(al)/institutions & 56 \\
\hline Studies/study & 54 \\
\hline International(isation)/internationalising & 49 \\
\hline New/newly & 45 \\
\hline Change(s)/changing & 40 \\
\hline System(s)/systemic & 40 \\
\hline Student(s) & 35 \\
\hline Market(isation)/marketing & 34 \\
\hline Perspective(s) & 34 \\
\hline Quality & 32 \\
\hline Autonomous/autonomy & 27 \\
\hline Governance/governing/government(al) & 31 \\
\hline Management/managerialism/managing & 31 \\
\hline Role(s) & 31 \\
\hline Challenge(s)/challenging & 31 \\
\hline Reform(s)/reformation & 24 \\
\hline Comparative/comparing/comparison & 39 \\
\hline Finance(s)/financial/financing & 37 \\
\hline
\end{tabular}

\section{The contributors}

There were 779 authors (of the total of 1,172 contributors, 67\%) appearing only once and 93 authors appearing twice. Twenty-nine authors had three papers in the journal and nine had four papers over the 25 years. Table 2 presents the most productive contributors to the journal (excluding myself), operationalised as having five papers or more throughout Higher Education Policy's history. A new entry in the top of the list - compared with the situation in 2008 - is Harry de Boer (Center for Higher Education Policy Studies, University of Twente). A surprise is the "sudden" appearance of Ka Ho Mok 
with seven publications on the third rank (most of these in special issues), remarkable because most of his contributions were in the past six years. The authors in table 2 are all well-known scholars in the field of higher education. Almost all are representatives of higher education research centres, Adel Aldosary being the odd one out as well as Guy Neave, although he was - apart from being director of research of the International Association of Universities (IAU) - affiliated to research centres in the UK, the Netherlands and Portugal.

Table 2 Most productive contributors to Higher Education Policy 1988 - 2013

\begin{tabular}{|c|c|c|c|c|c|c|c|c|c|}
\hline Rank & Name & Institution & Country & $\begin{array}{l}1988- \\
1992\end{array}$ & $\begin{array}{l}1993- \\
1997\end{array}$ & $\begin{array}{l}1998- \\
2002\end{array}$ & $\begin{array}{l}2003- \\
2007\end{array}$ & $2008-$ & Total \\
\hline 1 & U. Teichler & University of Kassel & Germany & 1 & 4 & 1 & 3 & & 9 \\
\hline 2 & A. Amaral & University of Porto & Portugal & & & 3 & 2 & 3 & 8 \\
\hline \multirow[t]{2}{*}{$3=$} & I. Bleiklie & University of Bergen & Norway & & 1 & & 5 & 1 & 7 \\
\hline & K.H.Mok & $\begin{array}{l}\text { University of Bristol, } \\
\text { University of Hong } \\
\text { Kong, Hong Kong } \\
\text { Institute of Education }\end{array}$ & Hong Kong/UK & & & 1 & & 6 & 7 \\
\hline \multirow[t]{3}{*}{$5=$} & P. Altbach & $\begin{array}{l}\text { University of New } \\
\text { York, Boston College }\end{array}$ & USA & 3 & 1 & 2 & & & 6 \\
\hline & H. de Boer & University of Twente & the Netherlands & 1 & & 3 & & 2 & 6 \\
\hline & G. Harman & $\begin{array}{l}\text { University of New } \\
\text { England }\end{array}$ & Australia & 1 & & 2 & 2 & 1 & 6 \\
\hline \multirow[t]{6}{*}{$8=$} & A. Aldosary & King Fahd University & Saudi Arabia & & 1 & 3 & 1 & & 5 \\
\hline & A. Magalhães & University of Porto & Portugal & & & 1 & 2 & 2 & 5 \\
\hline & L. Meek & $\begin{array}{l}\text { University of New } \\
\text { England }\end{array}$ & Australia & & 1 & 4 & & & 5 \\
\hline & G. Neave & IAU & France & 3 & & 2 & & & 5 \\
\hline & M. Trow & University of California & USA & & 2 & 2 & 1 & & 5 \\
\hline & H. Wasser & $\begin{array}{l}\text { City University of New } \\
\text { York }\end{array}$ & USA & 2 & 2 & 1 & & & 5 \\
\hline
\end{tabular}

Names of female authors are missing in this table, which does not imply however that they do not figure in the journal. On the contrary, a rough estimation yields that about $35-40 \%$ of the authors in the past five years were female. Authors like Åse Gornitzka, Rosemary Deem, Christine Teelken, Ludmila Verbitskaya and Inge van der Weijden each contributed with three papers to the journal. The special issue on gender in higher education from 2009 illustrates the increasing presence of female authors and attention to gender issues (see also Currie and Hill, 2013; Molla, 2013).

There is a clear trend from single-authored papers towards multi-authored papers, with the maximum number of authors for a paper being seven. This mirrors a trend visible in other fields and disciplines. A quick Internet search revealed that in some disciplines a paper by 50 authors or more is not that unusual; 3,221 being reported as the highest number of authors for a Thomson-Reuter indexed paper, based on work carried out with the Large Hadron Collider at CERN. In that sense, a paper written by seven authors in Higher Education Policy should not strike us as odd, particularly if such a paper is the result of a large international project. Over the first two decades $26 \%$ of the contributions were multi-authored. From 2008 on, a little bit more than half of the papers (53\%) was multi-authored. Another way to look at this is to count the number of contributors for each five-year period. This number is relatively stable in the first decade: 230 in 1988-1992, and 244 in 1993-1997. In the second decade, this then drops to 195 in 1998-2002 and 204 in 2003-2007. In the last five-year period (2008-2012), there is a sudden increase to 271 . Many of the multi-authored papers are 
written by representatives of different institutions from one country and (increasingly) by authors from different countries.

\section{Geography}

Not only do most-often appearing authors normally come from the largest higher education research centres, these centres are also responsible for high levels of overall production. The usual suspects appear in table 3 . For sure, the ranking is as much signalling creative production as it represents sheer size. That said, other sizeable research centres do not figure in the top-10, although centres located in Germany, the USA, Japan and Hong Kong do appear in the top-30.

Table 3 Most productive institutions contributing to Higher Education Policy 1988 - 2013

\begin{tabular}{|l|l|l|c|}
\hline Rank & Institution & Country & $\begin{array}{l}\text { Total number of } \\
\text { contributors }\end{array}$ \\
\hline & & & 40 \\
\hline 1 & University of Twente & the Netherlands & 28 \\
\hline 2 & University of Porto & Portugal & 27 \\
\hline 3 & University of California & USA & 18 \\
\hline 4 & University of New England & Australia & 16 \\
\hline 5 & NIFU & Norway & 15 \\
\hline 6 & Institute of Education & UK & 14 \\
\hline 7 & State University of New York & USA & 12 \\
\hline $8=$ & University of Bergen & Norway & 12 \\
\hline & University of Toronto & Canada & 12 \\
\hline & University of Nairobi & Kenya & \\
\hline
\end{tabular}

Tables 2 and 3 suggest a domination of authors and institutions in the Western world, and a particular dominance of countries in which English is the (or one of the) main language(s), with a few (but notable) exceptions. Table 4 confirms this pattern, but also shows that there are many contributions from China, Hong Kong and Japan. China and Hong Kong are definitely on the rise. Respectively, nine authors (of the total of 25 from China) and ten authors (of the total of 28 from Hong Kong) appeared in the period 2008-2012. 
Table 4 Countries contributing to Higher Education Policy 1988 - 2013

\begin{tabular}{|c|c|c|}
\hline Rank & Country & Total number of contributors \\
\hline 1 & USA & 185 \\
\hline 2 & UK & 107 \\
\hline 3 & the Netherlands & 85 \\
\hline 4 & Australia & 76 \\
\hline 5 & Canada & 56 \\
\hline 6 & Portugal & 47 \\
\hline 7 & Germany & 40 \\
\hline 8 & France & 36 \\
\hline 9 & Norway & 35 \\
\hline 10 & Israel & 29 \\
\hline 11 & Hong Kong & 28 \\
\hline 12 & China & 25 \\
\hline 13 & Japan & 23 \\
\hline 14 & Italy & 20 \\
\hline 15 & Finland & 18 \\
\hline
\end{tabular}

Table 5 shows the representation of the continents in the journal's history. Europe, North American and Asia are dominating the journal ( $80 \%$ of all authors). There are small changes when the five-year periods are compared, the increase for Europe between 1993-1997 and 1998-2002 and the decrease for Asia in the same period being notable. Overall, there are now fewer contributions from Africa and (particularly) Latin America than in the first decade.

Table 5: Continents contributing to Higher Education Policy 1988 - 2013 (\% between brackets)

\begin{tabular}{|l|r|r|r|r|r|r|}
\hline Continent & \multicolumn{1}{|c|}{$1988-1992$} & $1993-1997$ & $1998-2002$ & $2003-2007$ & $2008-$ & Total \\
\hline & & & & & & \\
\hline Australasia & $6(3)$ & $22(9)$ & $18(9)$ & $17(8)$ & $25(8)$ & $88(8)$ \\
\hline Europe & $102(44)$ & $81(33)$ & $87(45)$ & $88(43)$ & $153(51)$ & $511(44)$ \\
\hline North America & $48(21)$ & $52(21)$ & $42(22)$ & $47(23)$ & $52(17)$ & $241(21)$ \\
\hline Asia & $35(15)$ & $46(19)$ & $26(13)$ & $33(16)$ & $50(17)$ & $190(16)$ \\
\hline Latin America & $18(8)$ & $16(7)$ & $10(5)$ & $3(1)$ & $2(1)$ & $49(4)$ \\
\hline Africa & $18(8)$ & $27(11)$ & $12(6)$ & $16(8)$ & $17(6)$ & $90(8)$ \\
\hline unknown & $3(1)$ & & & & & $3(<1)$ \\
\hline
\end{tabular}

\section{Citations}

Finally, some attention will be paid to citations. The findings in this section should be interpreted with caution. Citations are used to construct impact factors for journals, as e.g. the Thomson Reuter annual Journal Citation Reports illustrate, but also the SCImago Journal Rank. Although citations do say something about the quality of the journal, it ultimately is an indicator of quality of an individual paper. 
The logic of using number of citations as a proxy for quality is that the more relevant, interesting, etc. a paper is, the more likely it is that the paper is cited by others. I phrase this carefully, for relevance and interest are to a large extent in the eye of the beholder, even if readers (and before these see the paper, the editor and reviewers) would share a basic understanding of what makes a good paper. This is of specific concern for an academic journal that aims to be of relevance for policy and practice as well. A paper in Higher Education Policy could be highly relevant to policy makers and institutional leaders and as such have high impact at the level of policy and practice. It is however unlikely that these policy-makers and leaders will abundantly cite the source, neither will academic scholars likely cite the paper. Conversely, a review article in the journal could be highly cited (as many review articles are), because it is a useful source for scholars as a point of departure for their own investigations. That does not tell us much yet about how novel the findings are. Because Harzing's web site uses Google Scholar as the database, both scholarly citations and citations in other documents (policy papers, conference papers, reports, etc.) are captured. As a technical aside: Harzing's web site showed almost all of the contributions to Higher Education Policy (the database consisted of 1,000 items), a larger sample than I used for the analyses presented above.

Bearing in mind that citation scores are proxies of (academic) quality, the following table presents the most cited papers in the journal's history.

Table 6 Fifteen most cited papers Higher Education Policy 1988 - 2013

\begin{tabular}{|c|c|c|c|}
\hline Cites & Authors & Title & Year \\
\hline 259 & M. Trow & Trust, markets and accountability in higher education: a comparative perspective & 1996 \\
\hline 200 & D.D. Dill & Higher education markets and public policy & 1997 \\
\hline 192 & M. Trow & Managerialism and the Academic Profession: The Case of England & 1994 \\
\hline 190 & M.C. van der Wende & Internationalisation policies: about new trends and contrasting paradigms & 2001 \\
\hline 139 & $\begin{array}{l}\text { K. Mohrman, W. Ma \& D } \\
\text { Baker }\end{array}$ & The research university in transition: The emerging global model & 2008 \\
\hline 129 & M. Shriberg & $\begin{array}{l}\text { Institutional assessment tools for sustainability in higher education: strengths, } \\
\text { weaknesses, and implications for practice and theory }\end{array}$ & 2002 \\
\hline 116 & $\begin{array}{l}\text { R. Deem, K.H. Mok \& L. } \\
\text { Lucas }\end{array}$ & $\begin{array}{l}\text { Transforming higher education in whose image? Exploring the concept of the } \\
\text { 'world-class' university in Europe and Asia }\end{array}$ & 2008 \\
\hline 109 & G. Williams & The market route to mass higher education: British experience 1979-1996 & 1997 \\
\hline 107 & P. Laredo & $\begin{array}{l}\text { Revisiting the third mission of universities: Toward a renewed categorization of } \\
\text { university activities? }\end{array}$ & 2007 \\
\hline 102 & J. Fien & $\begin{array}{l}\text { Advancing sustainability in higher education: issues and opportunities for } \\
\text { research }\end{array}$ & 2002 \\
\hline 98 & E. Hazelkorn & $\begin{array}{l}\text { Learning to live with league tables and ranking: The experience of institutional } \\
\text { leaders }\end{array}$ & 2008 \\
\hline 96 & I. Bleiklie \& M. Kogan & Organization and governance of universities & 2007 \\
\hline 95 & U. Teichler & $\begin{array}{l}\text { Higher education policy and the world of work: changing conditions and } \\
\text { challenges }\end{array}$ & 1999 \\
\hline 95 & V.L. Meek & Diversity and marketisation of higher education: incompatible concepts? & 2000 \\
\hline 91 & F. van Vught & Mission diversity and reputation in higher education & 2008 \\
\hline
\end{tabular}

The data have to be seen in perspective and one important feature of citations scores - in almost any journal - is a skewed distribution: against a few highly-cited papers there are many that are hardly or not cited. To illustrate this point for Higher Education Policy: $62 \%$ of the papers have less than 5 citations. Given this characteristic of citation distribution, the h-index is often used, for it yields 
better information than e.g. average and median. The $h$-index indicates the number of papers $(h)$ that has at least the same number ( $h$ ) of citations and can be applied to individual scholars and to journals. The h-index of Higher Education Policy is 43, meaning there are 43 papers in the journal with at least 43 citations.

To be able to gather a substantial number of citations, time is an important friend (or enemy, if one's career is dependent on citations!). The top-3 consists of papers that were published in the 1990s. But it is good to see that also some five-year old papers, written by Mohrman et al., Deem et al., Hazelkorn and Van Vught, have received considerable scholarly attention. It is difficult to detect the underlying patterns that predict successful citation. It appears that authors - beyond having written a good paper - have addressed salient themes (world-class universities, rankings, internationalisation, markets, managerialism, missions) that are or were much debated. It is worthy to note that the papers with high citations are certainly not the first ever papers written by these authors. In other words, they are written by mature scholars that build on a rich experience and have considerable expertise on issues in higher education. Also, to some extent a corollary of the former, they have analysed the phenomena mostly from a bird's eye perspective. The large majority of the papers are reflective and/or conceptual essays, making limited use of (new) empirical findings. And, related, the papers - apart from the second Trow paper and Williams' contribution, dealing with developments in England and Britain, respectively - reach beyond institutional and national boundaries. The pattern is confirmed, looking at the low-cited papers. These are generally much more focused on "smaller" topics, e.g. curriculum development, boards of trustees, and catholic higher education, to mention just a few. Geographically these papers are more often limited to a specific country or institution, and quite often on a country that may not necessarily be seen as a higher education hot spot.

\section{Reflections}

This paper - like its 2008 predecessor - has shown the journal's change and continuity over time. The outlook for the future is promising, with a fair amount of good papers in line for publication. Also, themes for a few special issues are currently discussed with guest editors. The journal has its full archive on-line and papers that have been accepted for publication are made visible through the advance on-line publication system. Further professionalisation and standardisation will be achieved through an on-line submission system. The people behind these systems remain extremely important and hence a big "thank you" to Nick Poulton (long-standing editorial assistant of the journal), Eva Egron-Polak (secretary-general of the Internationalisation Association of Universities) and David Bull (publishing director Palgrave Macmillan) and his team. And, many thanks to the reviewers that take the time to comment on submissions. Without proper peer review, the journal would not be what it currently is. On that note, allow me to make a plea. In the past years, I have noted - and other journal editors with me - that it becomes more and more difficult to find reviewers that (can) spare the time. The most frustrating thing for an editor is to wait (too) long and sometimes in vain for an unresponsive reviewer. It is frustrating for it unnecessarily prolongs the review period. Hence a plea for those approached to review: If you cannot meet the request to review, let us know immediately, and we can move on to find another reviewer. If you can do the review, please do meet the generally generous deadlines. 
The final paragraph is written for future submitters. Please submit or continue to submit your papers. The previous section of the paper may inspire you to also become a highly-cited Higher Education Policy scholar or to write another impressive paper that also could become an evergreen. Be assured that reviewers (through a double-blind review process) and I treat each paper on its intrinsic merits. Papers can be reflective essays, empirically-oriented papers or Forum contributions. They can be based on any methodology (as long as it is fit-for-purpose). Important, however, is that your paper does meet the standards when it comes to length, language and "proper" academic skills. I often receive lengthy papers that go far beyond the 7,000 word limit. Mindful of the Emperor Joseph II's comment on Mozart's work ("too many notes!"), I am happy to accept a very good paper that goes beyond the word limit, but would generally argue that authors must be able to get a message across - even a complex one! - within the scope of 6,000-7,000 words. Regarding language, it is important to submit something that is up to the standards. It is quite challenging for an editor and reviewers to judge a paper if language issues stand in the way. Please help us to avoid the difficult choice between "the author is simply wrong in arguing ..." and "some of the arguments suffer from linguistic shortcomings ....". Finally, be a "stickler for details". I use this quote from Noble's (1989) paper, presenting views from editors of journals on what constitutes a good submission, to illustrate how important details are. For sure, nobody is perfect and the odd mistake may slip in, but if a paper contains many typos, particularly in the references and in names of authors, this suggests a level of avoidable sloppiness. May these grumbles from the editor stimulate you to submit the first fully flawless paper!

\section{References}

Bray, N.J. and Major, C.H. (2011), 'Status of journals in the field of higher education', Journal of Higher Education 82(4): 479-503.

Currie, J. and Hill, B. (2013) 'Gendered universities and the wage gap: Case study of a pay equity audit in an Australian university', Higher Education Policy 26(1): 65-82.

Dobson, I. (2009), 'The Journal of Higher Education Policy and Management: An output analysis', Journal of Higher Education Policy and Management 31(1): 3-15.

Eberhard, F. and Thorens, J. (1988) 'Dear reader', Higher Education Policy 1(1): 6.

Goodyear, R.K., Brewer, D.J., Gallagher, K.S., Tracey, T.J.G., Claiborn, C.D., Lichtenberg, J.W. and Wampold, B.E. (2009) 'The intellectual foundations of education: Core journals and their impacts on scholarship and practice', Educational Researcher 38(9): 700-706.

Higher Education Policy (2013) Journal home, http://www.palgrave-journals.com/hep/index.html (visited 19 June).

Huisman, J. (2008) 'Higher Education Policy: the evolution of a journal' Higher Education Policy 21(3): 265-274.

Krücken, G. and F. Meier (2006) 'Turning the university into an organisational actor', in G. Drori, J. Meyer and $\mathrm{H}$. Hwang (eds.) Globalisation and organisation: World society and organisational change, Oxford: Oxford University Press, pp. 241-257.

Molla, T. (2013) 'Higher education policy reform in Ethiopia: The representation of the problem of gender equality', Higher Education Policy 26(2): 193-215.

Noble, K.A. (1989) 'Publish or perish: What 23 journal editors have to say', Studies in Higher Education 14(1), 97-102. 
Tight, M. (2012) Researching higher education. Maidenhead, Open University Press McGraw Hill Education.

'Thanks to Louisa Goedvree, University of the Universe, Bathford campus, Somerset, UK, for helping me with the data analysis. 